African Crop Science Journal by African Crop Science Society is licensed under a Creative Commons Attribution 3.0 Uganda License. Based on a work at www.ajol.info/ and www.bioline.org.br/cs DOI: http://dx.doi.org/10.4314/acsj.v26i3.4

\title{
DETECTION OF COWPEA APHID-BORNE MOSAIC VIRUS (CABMV) IN COWPEA BY REVERSE TRANSCRIPTION POLYMERASE CHAIN REACTION
}

\author{
E.K. MBEYAGALA, P. TUKAMUHABWA ${ }^{1}$ and S.B. MUKASA ${ }^{1}$ \\ National Semi-Arid Resources Research Institute (NaSARRI)/NARO, P. O. Box 56, Soroti, Uganda \\ ${ }^{1}$ School of Agricultural Sciences, Makerere University, P. O. Box 7062, Kampala, Uganda \\ Corresponding author: kmbeyagala@gmail.com
}

(Received 8 June, 2018; accepted 17 August, 2018)

\begin{abstract}
The occurrence of CABMV on cowpea (Vigna unguiculata L. Walp) in Uganda was described recently in several studies. This study developed and optimised a reverse transcription polymerase chain reaction (RT-PCR) based assay for the detection of CABMV in leaf samples, and compared it to previous RT-PCR and ELISA assays. Use of the forward primer (CABFF1, 5'- GGT AAC AAY AGT GGR CAA CC-3') and the reverse primer (CABRR1, 5'- CTG AGC ACT CMAACC GGG-3') yielded a product of 1,642 bp. Amplicon sequencing and subsequent BLASTN analysis showed that Ugandan isolates were 89.3-94.3\% identical indicating they belong to the same strain of CABMV. Phylogenetic analysis also placed the Ugandan isolates in the same cluster different from other isolates but closer to those from Burkina Faso. However, the previously reported RT-PCR assay (GF/GR primer pair) did not give the expected PCR fragment (221 bp) and gave no virus hits upon amplicon sequencing and sequence analysis. The ELISA assay did not differentiate between positive and negative samples. The newly developed RT-PCR assay for detecting CABMV, described in this study, has important applications for plant quarantine, resistance breeding, host range studies as well as epidemiological studies for the control of CABMV in the country.
\end{abstract}

Key Words: NCM-ELISA, RT-PCR, sequencing, Vigna unguiculata

\section{RÉSUMÉ}

L'apparition de CABMV sur le niébé (Vigna unguiculata $($ L.)) en Ouganda a été décrite récemment dans plusieurs études. Cette étude a développé et optimisé un essai basé sur la transcription inverse- réaction en chaine par polymérase (RT-PCR) pour la détection du CABMV dans les échantillons de feuilles, et la comparé aux essais précédents basés sur la RT-PCR et ELISA. L'usage de l'amorce direct (CABFF1, 5'- GGT AAC AAY AGT GGR CAA CC-3') et d'amorce réverse (CABRR1, 5'- CTG AGC ACT CMA ACC GGG-3') a donné 1,642 bp. Le séquençage d'amplicon et l'analyse subséquente de BLASTN ont montré que les isolats d'Ouganda étaient à 89,3-94,3\% identiques indiquant qu'ils appartiennent à la même souche de CABMV. Les analyses phylogénétiques ont aussi placé les isolats Ougandais dans la même classe qui est différente des autres isolats mais proche de ceux du Burkina-Faso. Néanmoins, les essais de RT-PCR (GF/GR paire d'amorces) précédents n'ont pas donné les fragments PCR espérés (221 bp) et n'ont donné aucune détection de virus à partir du séquençage d'amplicon et de l'analyse de la séquence. L'essai de l'ELISA n'a pas différencié entre les échantillons positifs et négatifs. L'essai RT-PCR nouvellement développé pour détecter le CABMV, décrit dans cette étude, a d'importantes 
applications pour la mise en quarantaine de la plante, sélection pour la résistance, les études des gammes d'hôtes ainsi que les études épidémiologiques pour le contrôle du CABMV dans le pays.

Mots Clés: NCM-ELISA, RT-PCR, séquençage, Vigna unguiculata

\section{INTRODUCTION}

Over 20 viruses have been reported on cowpea in several parts of the world (Hughes and Shoyinka, 2003; Lima et al., 2005), of which over eight viruses infect cowpea in Africa (Hughes and Shoyinka, 2003). While some of these viruses occur occasionally with local or minor importance, some are widely spread with significant economic importance (Hughes and Shoyinka, 2003). Cowpea aphid-borne mosaic virus (CABMV), of the family Potyviridae and genus Potyvirus, is one of the viruses reported to cause the most important viral disease on cowpea in Africa (Taiwo, 2003). CABMV was first reported in Uganda in 1981 (Anon, 1981) and is now widely distributed in the main cowpea growing areas of the country (Orawu et al., 2005, 2015).

Using next-generation sequencing (NGS), the first complete genome sequence for a Ugandan isolate (Serere 1) of CABMV was recently published by Mbeyagala et al. (2018). Transmission of CABMV through seed is variable, but can be as high as $80 \%$ (Ojuederie et al., 2009), and is efficiently vectored by several aphid species such as Aphis craccivora, A. fabae, A. gossypii, A. medicaginis, Macrosiphum euphorbiae and Myzus persicae (Bashir et al., 2002).

The worldwide nature of CABMV occurrence (Bashir et al., 2002) pauses a serious threat of further spread through seed shipments. CABMV alone can cause yield losses of up to 60\% (Neya et al., 2015), but can also interact with other viruses leading to severe mosaic diseases (Lima et al., 2005; Taiwo et al., 2007).

Previous molecular diagnostic work on the same virus was reported by Gillaspie et al. (2001) on groundnuts. Their study yielded a diagnostic amplicon of 221 bp. However, validation of this assay on CABMV infected plants from Uganda did not yield the same amplicon (Amayo, 2008). This could have been due to difference in the strains and the nonspecificity of the primers used in a different host. This study was designed to optimise molecular detection of CABMV in cowpea, through design of new primer sets and reverse transcriptase-polymerase chain reaction (RTPCR) conditions.

\section{MATERIALS AND METHODS}

Plant samples. Fourty leaf samples from plants characteristic virus symptoms were collected from farmers' fields in Serere and Ngora districts in eastern Uganda during first season of 2017. The leaves were dried by placing them between paper towels; and inserted in ziploc bags, and silica gel added. The bags were placed horizontally in a plastic container and tightly closed. Complete drying of samples was achieved in 2-3 days at room temperature, with at least a single change of silica gel. The dried leaf samples were used for RNA extraction and virus detection by RTPCR. Forty fresh leaf samples were also collected and kept in cool boxes $\left(4-8{ }^{\circ} \mathrm{C}\right)$ containing ice for serological assay, using Nitrocellulose membrane based ELISA (NCMELISA).

Nitrocellulose membrane based ELISA (NCM-ELISA). NCM-ELISA procedure was carried out as described by Fuentes (2010). Positive and negative controls, as well as the $1^{\text {st }}$ antibody and the $2^{\text {nd }}$ antibody (conjugated with alkaline phosphatase), were obtained from DSMZ (Braunschweig, Germany). The substrate-chromogen solution, BCIP/NBT (5Bromo-4-chloro-3-indolyl phosphate/nitro-blue tetrazolium chloride), was obtained from 
Sigma (St. Louis, USA). Colour development was stopped by discarding the substrate solution and immersing the membrane in distilled water for $10 \mathrm{~min}$. Positive reactions were identified by purple coloration of blots; while negative samples remained blue.

RNA extraction and cDNA synthesis. Dried leaf samples were ground into powder using sterile mortars and pestles; with the help of liquid nitrogen. RNA extraction was carried out using AccuZol reagent (Bioneer, Seoul, Republic of Korea), according to the manufacturer's instructions. Quality was checked using TAE/Formamide agarose gel electrophoresis, as described by (Masek et al., 2005); and quantified using NanoDrop spectrophotometer (Thermo Fisher Scientific, Massachusetts, USA). RNA samples showing intact $18 \mathrm{~S}$ and $28 \mathrm{~S}$ subunits on agarose gel were used for cDNA synthesis. The oligo $(\mathrm{dT})_{18}$ primed synthesis of complementary DNA (cDNA) on $2 \mu \mathrm{g}$ of total RNA was achieved using RevertAid Reverse Transcriptase (RT), a recombinant M-MuLV RT according to manufacturer's instructions (Thermo Fisher Scientific, Massachusetts, USA).
Primer sequences used. Primers for virus detection were designed based on available sequence data (from DDBJ/ENA/ GenBank) from full genome sequences for the forward primers, and partial sequences at the $3^{\prime}-$ untranslated regions (3'-UTR) of CABMV, for reverse primers. The sequences were aligned using multiple alignment softwares; ClustalX Version 1.83 (Thompson et al., 1997) and MEGA7 (Kumar et al., 2016). Following the multiple alignment, five primer pairs (Table 1) were designed with the forward/left primer for the first pair starting at the conserved GNNSGQ motif located in the center of the nuclear inclusion protein $\mathrm{b}$ (NIb) (Zheng et $a l ., 2010)$. Subsequent forward primers were located downstream of the GNNSGQ motif. Reverse/right primer sets were designed in the 3'UTR regions. An additional primer pair (GF/ GR) designed by Gillaspie et al. (2001) was also included.

Polymerase chain reaction (PCR) conditions. Following optimisation of PCR conditions, only CABFF1/CABRR1 out of the five primer pairs was effective; thus further sections on methodology, results and

TABLE 1. Primers used for detection of CABMV in Ugandan cowpea samples

\begin{tabular}{llcl}
\hline Name & Primer sequence (5'-3') & Predicted size (bp) & Source \\
\hline CABFF1 & GGT AAC AAY AGT GGR CAA CC & 1,642 & This study \\
CABRR1 & CTG AGC ACT CMA ACC GGG & & \\
CABFF2 & GAG AGG YTR GTK TTC TTT GC & 1,514 & This study \\
CABRR2 & GGC CTC YCY GCT AAG TTC & & This study \\
CABFF3 & TGA ATT AYG AYT TCT CAG AAA G & 1,333 & \\
CABRR3 & CTG RAT ATA TGC GTA CTA TTT AC & & This study \\
CABFF4 & AGA GAR GAR TTA TGG TTC ATG & 1,281 & \\
CABRR4 & CTA AAA CCA ACC ATT AGC & & This study \\
CABFF5 & TAC ATA CCA AAR CTW GAG C & 1,275 & \\
CABRR5 & CCA CAC TRR CAT ATA TAG & & Gillaspie et al. (2001) \\
GF & CGCTCAAACCCATTGTAGAA & \multirow{2}{*}{221} & \\
GR & TATTGCTTCCCTTGCTCTTTC & & \\
\hline
\end{tabular}


discussions are limited to this primer set as well as GF/GR primer set designed by Gillaspie et al. (2001). The PCR mix consisted of $10 \mu \mathrm{l}$ of 2X PCR Master mix (Bioneer, Seoul, Republic of Korea), $0.25 \mu \mathrm{M}$ of each primer, $1 \mu \mathrm{l}$ of cDNA and $8 \mu \mathrm{l}$ of sterile nuclease free water giving a total reaction volume of $20 \mu \mathrm{l}$. The PCR conditions for CABFF1/CABRR1 was $94{ }^{\circ} \mathrm{C}$ for $2 \mathrm{~min}$, followed by 35 cycles of $94{ }^{\circ} \mathrm{C}(30 \mathrm{sec}), 58^{\circ} \mathrm{C}(90 \mathrm{sec}), 72{ }^{\circ} \mathrm{C}(90 \mathrm{sec})$ for denaturation, annealing and extension, respectively; with a final extension at $72^{\circ} \mathrm{C}$ for $5 \mathrm{~min}$. The PCR conditions used for GF/GR were as described by Gillaspie et al. (2001).

PCR products were analysed by electrophoresis in $1 \%$ agarose gel in $1 \times$ TAE buffer, and stained with ethidium bromide. Gel electrophoresis was carried out at $100 \mathrm{~V}$ for $60 \mathrm{~min}$. After electrophoresis, images of the PCR products were captured/visualised using an inbuilt camera in an E-Gel@ Imager System (Thermo Fisher Scientific, Massachusetts, USA) under UV light.

Amplicon sequencing and sequence analysis. The PCR products were purified from the gel using Wizard SV Gel and PCR Clean-Up System (Promega, Madison, USA), following the manufacturer's instructions, and directly sequenced. Sequencing was carried out at Macrogen Inc (Macrogen Europe Laboratory, Amsterdam, The Netherlands). Sequence data were compared to published DNA sequences using a Basic Local Alignment Search Tool (BLAST), as described by Johnson et al. (2008). Related sequences identified through BLASTN analysis were used in phylogenetic analysis. A total of 21 sequences, including an out group (Barley yellow dwarf virus-BYDV) were included in the analysis.

Multiple sequence alignment and computation of nucleotide sequence identities were done using the BioEdit software version 7.0.5 (Hall, 1999). Phylogenetic relationships were inferred using the Maximum Likelihood method, based on the Tamura-Nei model (Tamura and Nei, 1993) implemented in
MEGA7.0 (Kumar et al., 2016). Initial tree(s) for the heuristic search were obtained automatically, by applying Neighbor-Joining and BioNJ algorithms, to a matrix of pairwise distances estimated using the Maximum Composite Likelihood (MCL) approach, and then selecting the topology with superior $\log$ likelihood value. The trees were drawn to scale, with branch lengths measured in the number of substitutions per site.

Statistical significance of branching for phylogenetic trees was assessed using bootstrap analyses of 1,000 different alignments from the original dataset, and reported as percentage.

\section{RESULTS}

Virus detection by NCM-ELISA. CABMV was detected in all plant samples by NCMELISA, including the positive and negative controls. NCM-ELISA, therefore, was not able to distinguish between positive and negative samples, since all samples gave positive signals.

Virus detection by RT-PCR. Among the six primer pairs that were designed, only one primer (CABFFI/CABRRI) was able to give CABMV amplification when tested on the positive controls. The primer pair was, therefore, used to differentiate all collected samples into negative and positives. CABFFI/ CABRRI primer pair yielded the expected PCR product of approximately 1,642 bp (Fig. 1). However, the GF/GR primer designed by Gillaspie et al. (2001) produced a PCR product of about $400 \mathrm{bp}$ instead of the expected 221 bp (Fig. 2).

BLAST and pairwise sequence comparison of CABMV isolates. BLAST analysis (BLASTN) of nucleotide sequences from CABFF1/CABRR1 amplicons from Ugandan CABMV isolates showed similarity to coat protein $(\mathrm{CP})$ sequences of other CABMV isolates in the DDBJ/ENA/GenBank (Fig. 3). However, BLAST analysis of sequence data 


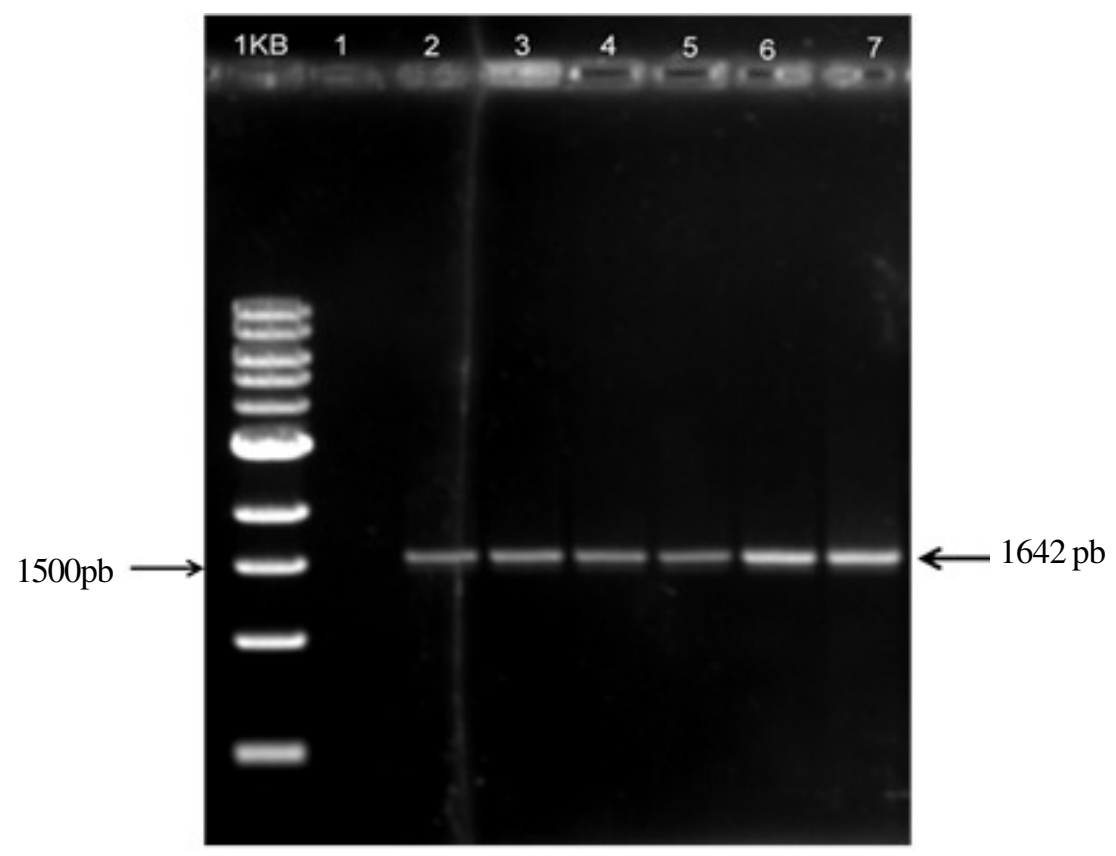

Figure 1. RT-PCR product for CABMV resulting from CABFFI/CABRR1 primer pair: Lane 1: Negative control, lanes 2-6: Samples, lane 7: Positive control.

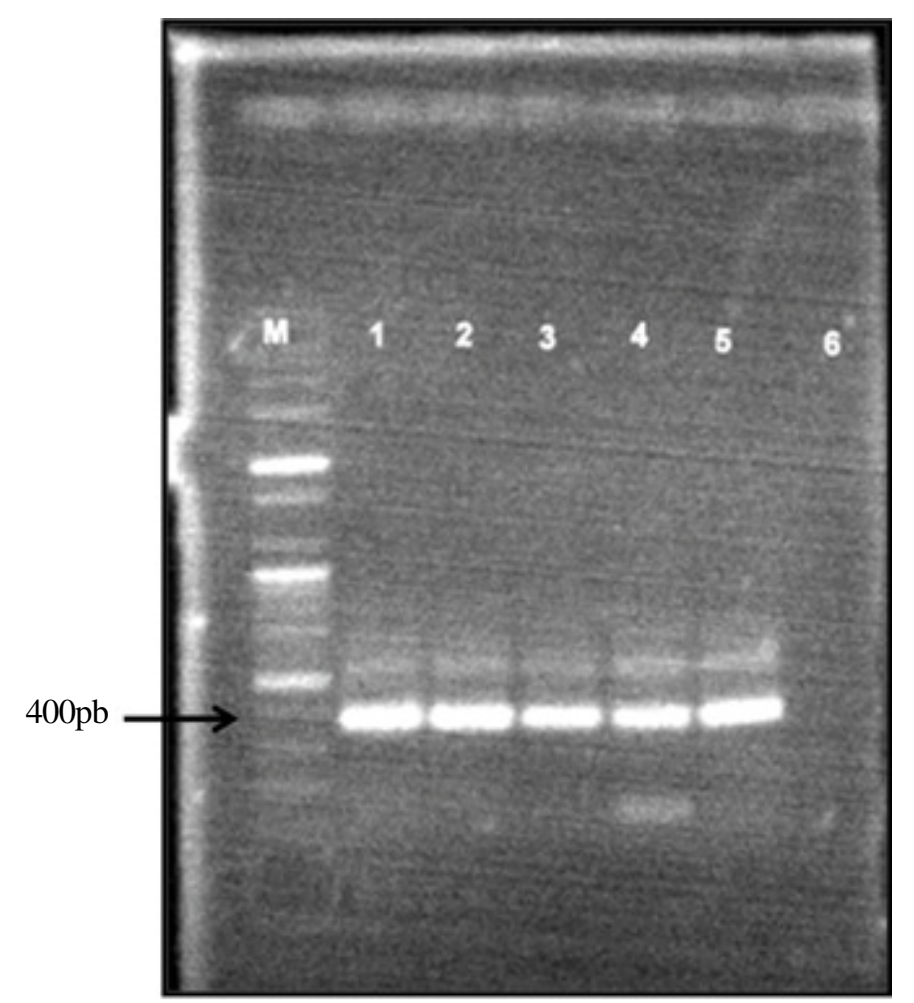

Figure 2. RT-PCR product for CABMV for GF/GR primer pair: $M$ is 100 bp ladder, lane 1-5: Samples, lane 6: Negative control. 
Cowpea aphid-borne mosaic virus isolate BF-E1 coat protein gene, partial cds Sequence ID: MF277031.1 Length: 828 Number of Matches: 1

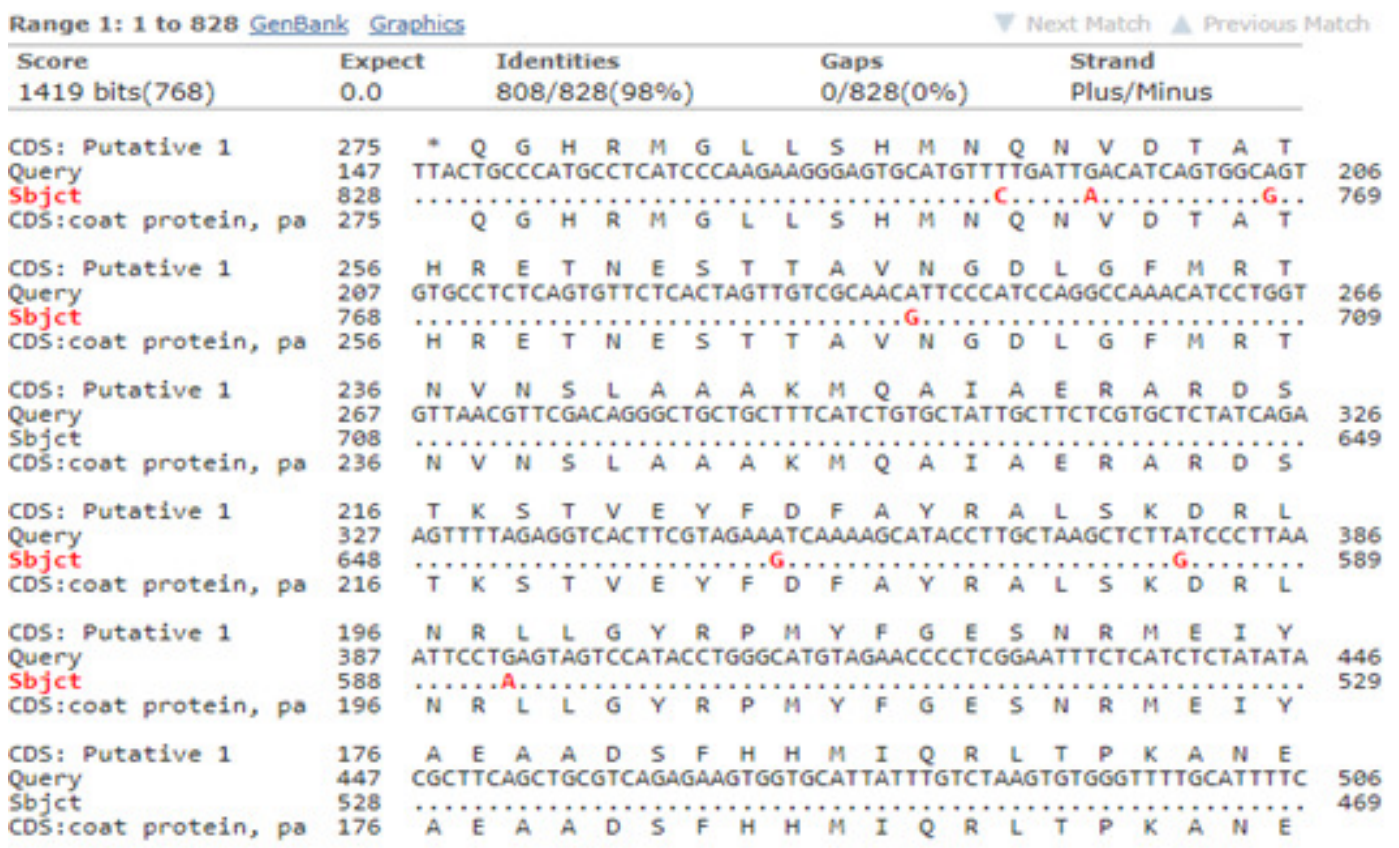

Figure 3. NCBI BLAST of sequence data for the RT-PCR fragments from CABFF1/CABRR1 primer.

from GF/GR primer fragments gave no virus hits (there were no significant alignments) (Fig. 4). Nucleotide sequences for three Ugandan CABMV isolates (CABMV-H1, CABMV-H2 and CABMV-H5) were deposited in the DDBJ/ ENA/GenBank under accession numbers MH151199, MH151200 and MH151201, respectively. Sequences for these isolates contained a single open reading frame (ORF) of 278 aa encoding the entire coat protein $(\mathrm{CP})$ followed by a non coding region of $147 \mathrm{nt}$, $150 \mathrm{nt}$ and $144 \mathrm{nt}$, excluding the poly A tail for CABMV-H1, CABMV-H2 and CABMV-H5, respectively.

The Ugandan CABMV isolates exhibited 62$75 \%$ nucleotide identity with CABMV isolates from Brazil, 72-75\% identity with and isolate from Nigeria and 68-75\% identity with isolates from Burkina Faso (Table 2). The molecular diversity among the Ugandan CABMV isolates was very limited, ranging from 89-94\% with the lowest identity observed between CABMV$\mathrm{H} 1$ and CABMV-H5.
Phylogenetic analysis of CABMV isolates. Phylogenetic analysis showed little divergence among CP sequences for the three Ugandan isolates as shown by the very short branch lengths. It is, therefore, possible that the three isolates belong to the same strain of CABMV. The Ugandan isolates were closely related to other CABMV isolates from Burkina Faso, but very different from Brazilian isolates (Fig. 5).

\section{DISCUSSION}

Virus detection by NCM-ELISA. NCMELISA test was unable to distinguish between positive and negative samples, since all samples gave positive signals. ELISA tests are often associated with giving false signals (false positives) and this could be associated with cross reaction of antibodies with plant proteins or other viruses (Dietzgen et al., 2001; Gutierrez et al., 2003; Kashif, 2009). Cross reaction makes it difficult to correctly distinguish/separate infected from non- 
Vigna radiata var. radiata mitochondrial DNA, complete sequence, cultivar: NM92 Sequence ID: AP014716.1 Length: 401262 Number of Matches: 2

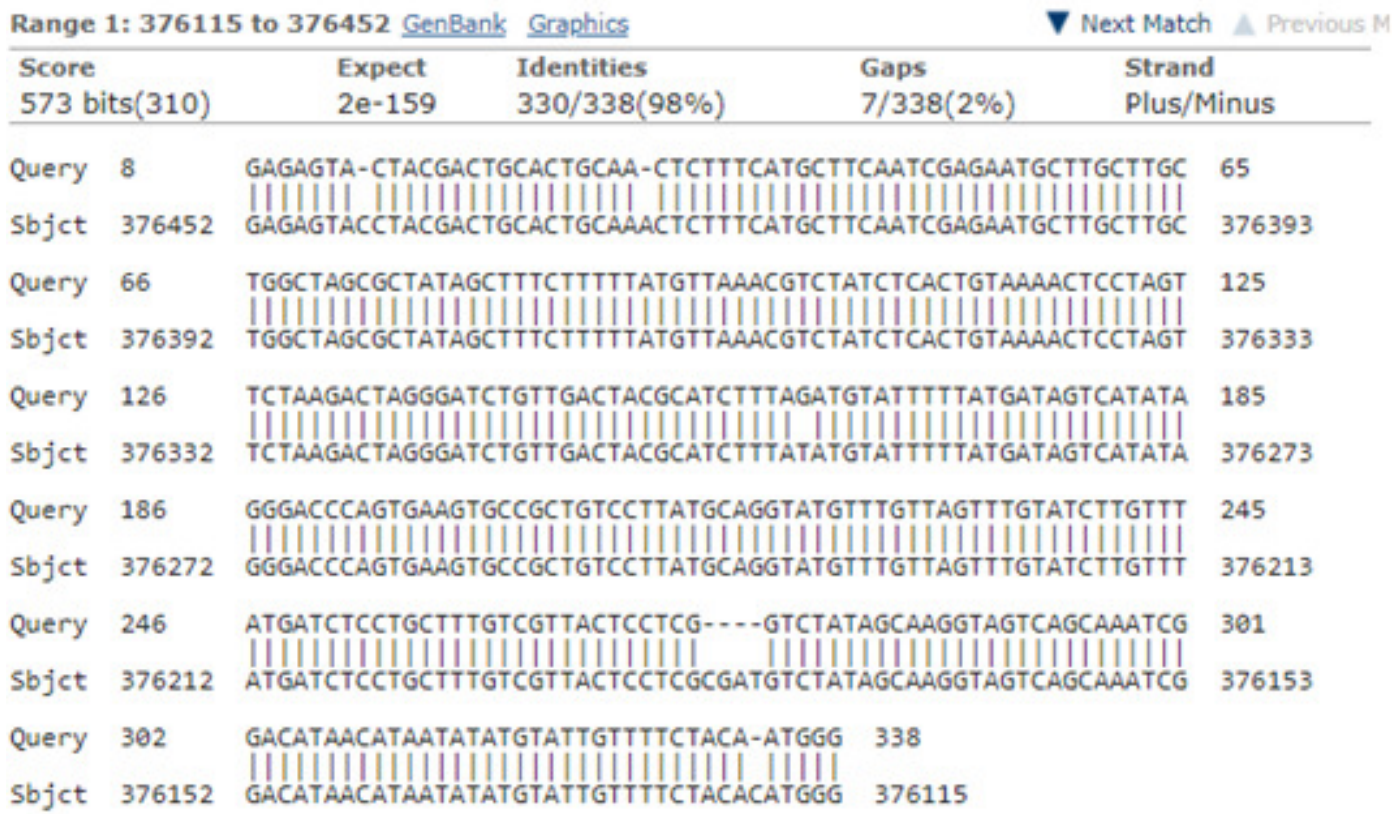

Figure 4. NCBI BLAST of sequence data for the RT-PCR fragments from GF/GR primer.

infected samples, rendering accurate virus detection impossible. Cross adsorption of membranes with extracts (plant sap) from healthy plants was reported as efficient in preventing reaction of antibodies with plant proteins in sweet potato (Gutierrez et al., 2003). The potential of cross adsorption with cowpea plant extracts, therefore, needs to be evaluated.

Virus detection by RT-PCR. An RT-PCR assay optimised in this study using a newly designed CABFFI/CABRR1 primer was able to detect CABMV in the infected cowpea plant samples that were tested. This primer set yielded the expected amplification of 1,642 bp (Fig. 1). While reverse transcriptase PCR (RTPCR) is a reliable method for diagnosis and allows for further characterisation of cowpea viruses (Akinjogunla et al., 2008), not all RTPCR assays are efficient. An earlier protocol described by by Gillaspie et al. (2001) failed to detect CABMV in positive samples in this study (Fig. 2), as was observed by Amayo (2008). However, other studies using the protocol by Gillaspie et al. (2001) reported its ability to give the expected fragment size (221 bp) (Byarugaba, 2008; Amayo et al., 2012). Non-specificity of the RT-PCR assays could be attributed to nucleotide differences in sequences used to design diagnostic primers. Primers designed by Gillaspie et al. (2001) were based on a single Brazilian CABMV strain and, thus were strain specific. However, in the present study, alignment of multiple sequences from different strains improved the specificity of the diagnostic primer (CABFFI/ CABRR1) and, therefore, improved its efficiency for detection of CABMV in Uganda.

BLAST, pairwise sequence comparison and phylogenetic analysis of CABMV isolates. Molecular analysis of the $\mathrm{CP}$ fragments amplified using the CABFFI/CABRR1 clearly identified them as CABMV belonging to the family Potyviridae (Fig. 3). In the present 
TABLE 2. Pairwise sequence comparison matrix for complete coat protein nucleotide sequences of three Ugandan isolates and other isolates of CABMV

\begin{tabular}{|c|c|c|c|c|c|c|c|c|c|c|c|c|c|c|c|c|c|c|c|c|c|}
\hline Virus isolate & 1 & 2 & 3 & 4 & 5 & 6 & 7 & 8 & 9 & 10 & 11 & 12 & 13 & 14 & 15 & 16 & 17 & 18 & 19 & 20 & 21 \\
\hline \multicolumn{22}{|l|}{ CABMV-BF-E4 } \\
\hline CABMV-BF-E1 & 99.1 & & & & & & & & & & & & & & & & & & & & \\
\hline CABMV-BF-E5 & 95.2 & 95.2 & & & & & & & & & & & & & & & & & & & \\
\hline CABMV-BF-E10 & 95.2 & 95.2 & 100 & & & & & & & & & & & & & & & & & & \\
\hline CABMV-BF-E6 & 95.4 & 95.4 & 99.8 & 99.8 & & & & & & & & & & & & & & & & & \\
\hline CABMV-M3 & 64.7 & 64.6 & 64.6 & 64.6 & 64.5 & & & & & & & & & & & & & & & & \\
\hline CABMV-M2 & 64.8 & 64.7 & 64.9 & 64.9 & 64.9 & 98.6 & & & & & & & & & & & & & & & \\
\hline CABMV-SP & 63.5 & 63.4 & 63.3 & 63.3 & 63.2 & 95.1 & 94.6 & & & & & & & & & & & & & & \\
\hline CABMV-Lns10 & 64.0 & 63.7 & 63.3 & 63.3 & 63.2 & 84.8 & 84.9 & 83.4 & & & & & & & & & & & & & \\
\hline CABMV-Lns9 & 64.0 & 64.0 & 63.6 & 63.6 & 63.5 & 84.7 & 84.9 & 83.1 & 99.3 & & & & & & & & & & & & \\
\hline CABMV-Lns4 & 63.9 & 63.8 & 63.2 & 63.2 & 63.1 & 84.7 & 84.9 & 83.3 & 99.2 & 98.9 & & & & & & & & & & & \\
\hline CABMV-Lns3 & 63.9 & 63.8 & 63.4 & 63.4 & 63.3 & 84.9 & 85.0 & 83.4 & 99.6 & 99.3 & 99.0 & & & & & & & & & & \\
\hline CABMV-Lns2 & 64.0 & 63.9 & 63.5 & 63.5 & 63.4 & 84.9 & 85.1 & 83.4 & 99.6 & 99.7 & 99.0 & 99.6 & & & & & & & & & \\
\hline CABMV-DF-Brs & 63.8 & 63.7 & 63.1 & 63.1 & 63.0 & 91.9 & 91.8 & 90.4 & 85.8 & 85.9 & 86.0 & 85.9 & 85.9 & & & & & & & & \\
\hline CABMV-F-144 & 64.9 & 64.8 & 65.0 & 65.0 & 64.9 & 98.1 & 99.4 & 94.6 & 85.0 & 84.9 & 85.0 & 85.1 & 85.2 & 92.0 & & & & & & & \\
\hline CABMV-F-101 & 63.4 & 63.3 & 63.6 & 63.6 & 63.5 & 96.2 & 97.4 & 96.5 & 83.4 & 83.3 & 83.0 & 83.5 & 83.6 & 90.1 & 97.4 & & & & & & \\
\hline CABMV-A132 & 56.1 & 55.9 & 55.3 & 55.3 & 55.2 & 77.3 & 77.6 & 76.0 & 77.3 & 77.1 & 77.0 & 77.3 & 77.3 & 77.8 & 77.6 & 76.0 & & & & & \\
\hline CABMV-H1 & 74.5 & 74.4 & 72.4 & 72.4 & 72.5 & 69.0 & 69.1 & 68.0 & 74.7 & 74.5 & 75.0 & 74.7 & 74.6 & 68.2 & 69.2 & 68.0 & 72.1 & & & & \\
\hline CABMV-H2 & 71.6 & 71.5 & 69.7 & 69.7 & 69.7 & 66.7 & 66.8 & 65.7 & 72.1 & 71.9 & 72.0 & 72.1 & 72.1 & 65.8 & 66.9 & 66.0 & 74.8 & 94.3 & & & \\
\hline CABMV-H5 & 69.6 & 69.5 & 67.7 & 67.7 & 67.8 & 63.2 & 63.3 & 62.5 & 68.6 & 68.3 & 68.0 & 68.6 & 68.5 & 62.6 & 63.3 & 62.0 & 73.4 & 89.3 & 93.4 & & \\
\hline BYDV-Montana & 30.1 & 30.0 & 29.8 & 29.8 & 29.8 & 30.0 & 30.1 & 29.5 & 29.6 & 29.7 & 30.0 & 29.6 & 29.6 & 29.3 & 30.1 & 29.0 & 25.5 & 27.7 & 26.8 & 25.3 & \\
\hline
\end{tabular}

aPair wise comparisons made with BioEdit version 7.0.4.1, derived using ClustalW multiple alignments with the following parameters: BLOSUM matrix, Gap open $=10$, Gap extension $=0.1$ 


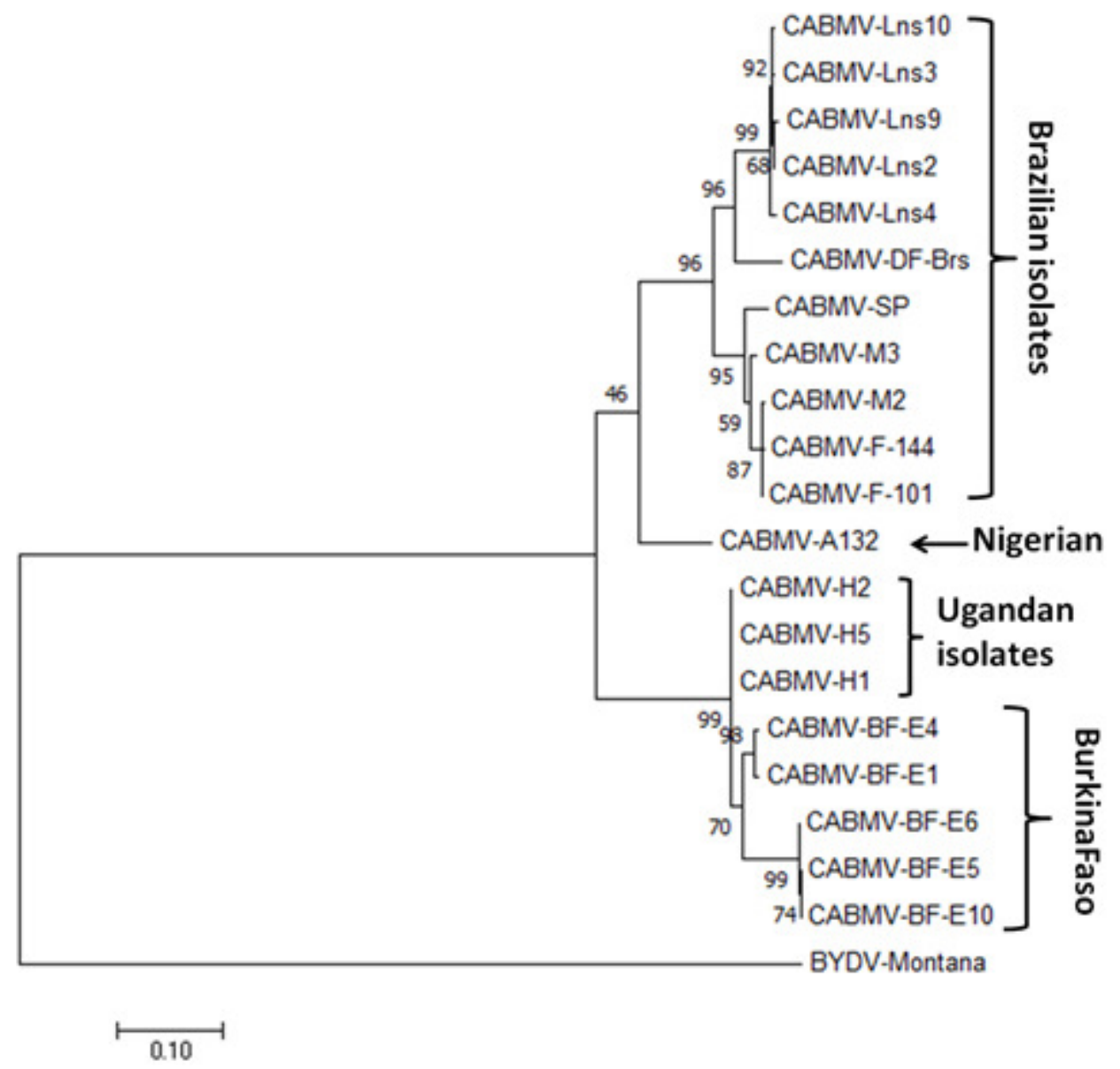

Figure 5. Phylogenetic tree based on alignments of complete coat protein nucleotide sequences of three CABMV isolates from Uganda and isolates from other countries. The tree was rooted on the sequence of Barley yellow dwarf virus.

study, sequence analysis of fragments from the assay by Gillaspie et al. (2001) did not give any hits related to CABMV (Fig. 4) and, therefore, was unable to detect the virus in Uganda. The criteria set by the International Committee for Taxonomy of Viruses (Adams et al., 2011) and other taxonomic studies (Adams et al., 2005) suggested a benchmark for species demarcation in the family Potyviridae as a nucleotide sequence identity of less than $76 \%$, either in the CP or over the whole genome. Using this criteria, the three virus isolates from cowpea are all the same species (Table 2) belonging to the same strain of CABMV (Fig. 5).

\section{CONCLUSION}

Using a newly designed primer pair (CABFFI/ CABRR1), we have optimised a reliable and accurate RT-PCR assay for detection of CABMV in cowpea leaf samples. The assay produced a PCR fragment of approximately $1,642 \mathrm{bp}$, which upon sequencing yielded the complete CP region of CABMV. The new assay clearly distinguished between positive and negative samples that could not be distinguished using NCM-ELISA. Sequencing of amplicons for the Ugandan CABMV isolates tested using the assay and subsequent phylogenetic analysis showed that they belong 
to the same strain of CABMV. Further studies utilising the new diagnostic assay are needed to determine the distribution of CABMV in the main cowpea growing areas of the Uganda. The assay will also be applicable in cowpea breeding to aid selection of virus resistant progenies. Additionally, this assay will contribute to efficient screening of samples before exist or entry (international exchange of germplasm and quarantine protection) into the country, thus limiting the spread of the virus. Since CABMV has a wide host range infecting both legumes and non legumes, the new assay can also be used to detect CABMV in alternative hosts in the country.

\section{ACKNOWLEDGEMENT}

This study was supported with funding from the McKnight Foundation, through the Collaborative Crop Research Program (CCRP). Partial funding provided by Carnegie Cooperation of New York (Grant \# RU/2016 / Carnegie/DFS/001) through the Regional Universities Forum for Capacity Building in Agriculture (RUFORUM) and the Government of Uganda (GoU) is duly acknowledged.

\section{REFERENCES}

Adams, M.J., Zerbini, F.M, French, R., Rabenstein, F., Stenger, D.C. and Valkonen, J.P.T. 2011. Family Potyviridae. In: King, A.M.Q., Adams, M.J., Carstens, E.B. and Lefkowitz, E.J. (Eds.), Virus Taxonomy, Ninth Report of the International Committee on Taxonomy of Viruses. Elsevier Academic Press, London, UK. pp. 10691089.

Adams, M.J., Antoniw, J.F. and Fauquet, C.M. 2005. Molecular criteria for genus and species discrimination within the family Potyviridae. Archives of Virology 150(3):459-479. https://doi.org/10.1007/ s00705-004-0440-6.

Akinjogunla, O.J., Taiwo, M.A. and Kareem, K.T. 2008. Immunological and molecular diagnostic methods for detection of viruses infecting cowpea ( Vigna unquiculata). African Journal of Biotechnology 7(13):2099-2103.

Amayo, R. 2008. Occurrence and transmission of seed-borne cowpea viruses in Uganda. MSc. Thesis, Makerere University, Kampala, Uganda. 70pp.

Amayo, R., Arinaitwe, A.B., Mukasa, S.B., Tusiime, G., Kyamanywa, S., Rubaiyaho, P.R. and Edema, R. 2012. Prevalence of viruses infecting cowpea in Uganda and their molecular detection. African Journal of Biotechnology 11(77):14132-14139. https://doi.org/10.5897/AJB11.398.

Anonymous. 1981. Viruses, virus-like diseases and mycoplasma-like diseases. In: Pest control in tropical grain legumes. Centre for Overseas Pest Research, London, United Kingdom. pp. 95-110.

Bashir, M., Ahmad, Z. and Ghafoor, A. 2002. Cowpea aphid-borne mosaic potyvirus: A review. International Journal of Pest Management 48(2):155-168. https:// doi.org/10.1080/09670870110118722.

Byarugaba, A.A. 2008. Occurrence and pathogenesis of cowpea viruses in Uganda. MSc. Thesis, Makerere University, Kampala, Uganda. 69pp.

Dietzgen, R.G., Callaghan, B., Higgins, C.M., Birch, R.G., Chen, K. and Xu, Z. 2001. Differentiation of peanut seed-borne potyviruses and cucumoviruses by RTPCR. Plant Disease 85(9):989-992.

Fuentes, S. 2010. NCM-ELISA detection of sweetpotato viruses. OP21, Version 56. International Potato Center (CIP), Lima, Peru. 5pp.

Gillaspie, A.G., Pio-Ribeiro, G., Andrade, G.P. and Pappu, H.R. 2001. RT-PCR detection of seedborne cowpea aphid-borne mosaic virus in peanut. Plant Disease 85:11811182.

Gutierrez, D.L., Fuentes, S. and Salazar, L.F. 2003. Sweet potato virus disease (SPVD): Distribution, incidence, and effect on sweet potato yield in Peru. Plant Disease 87:297302. 
Hall, T.A. 1999. BioEdit: A user-friendly biological sequence alignment editor and analysis program for Windows 95/98/NT. Nucleic Acids Symposium Series 41:95-98.

Hughes, J. d'A. and Shoyinka, S.A. 2003. Overview of viruses of legumes other than groundnut in Africa. In: Proceedings of a conference organized by IITA/ : 4-8 June 2001. International Institute of Tropical Agriculture. Ibadan, Nigeria. pp. 553-568.

Johnson, M., Zaretskaya, I., Raytselis, Y., Merezhuk, Y., McGinnis, S. and Madden, L. T. 2008. NCBI BLAST: A better web interface. Nucleic Acids Research 36(2):W5-W9. https://doi.org/10.1093/ nar/gkn201.

Kashif, M. 2009. Detection and characterization of viruses of sweet potatoes (Ipomoea batatas L.) from Guatemala and Honduras. MSc. Thesis, University of Helsinki, Finland. 72 pp.

Kumar, S., Stecher, G. and Tamura, K. 2016. MEGA7: Molecular Evolutionary Genetics Analysis version 7.0 for bigger datasets. Molecular Biology and Evolution 33:18701874.

Lima, J.A.A., Sittolin, I. M. and Lima, R.C.A. 2005. Diagnosis and strategies to control diseases caused by viruses. In: Freire Filho, F.R., Lima, J.A. de. A . and Ribeiro, V.Q (Eds.), Cowpea beans: technological advances., DF: Embrapa Technological Information; Teresina: Embrapa MeioNorte, Brasília, Brazil. Chapter 11. pp. 403459.

Masek, T., Vopalensky, V., Suchomelova, P. and Pospisek, M. 2005. Denaturing RNA electrophoresis in TAE agarose gels. Analytical Biochemistry 336(1):46-50. https://doi.org/10.1016/j.ab.2004.09.010.

Mbeyagala, E.K., Tukamuhabwa, P., Bisikwa, J., Holton, T. and Mukasa, S.B. 2018. Nextgeneration sequencing reveals the first complete genome sequence of Cowpea aphid-borne mosaic virus from Uganda. Genome Announcements 6:e1491-17. https://doi.org/10.1128/ genome A.0149117.

Néya, B.J., Zida, P.E., Sérémé, D., Lund, O.S. and Traoré, O. 2015. Evaluation of yield losses caused by cowpea aphid-borne mosaic virus (CABMV) in 21 cowpea (Vigna unguiculata (L.) Walp.) varieties in Burkina Faso. Pakistan Journal of Biological Sciences 18 (7):304-313. https:/ /doi.org/10.3923/pjbs.2015.304.313.

Ojuederie, O.B., Odu, B.O. and Ilori, C.O. 2009. Serological detection of seed borne viruses in cowpea regenerated. African Crop Science Journal 17(3):125-132.

Orawu, M., Melis, R., Milliano, W.D., Laing, M. and Adipala, E. 2005. Occurrence and prevalence of cowpea virus diseases in Uganda. Africana Crop Science Proceedings 7:1279-1283.

Orawu, M., Obuo, J. and Omadi, R. 2015. Distribution and detection of cowpea viruses infecting cowpea in Uganda. American Journal of Plant Sciences 6(5):574-581. https://doi.org/10.4236/ ajps.2015.65062.

Salem, N., Ehlers, J. and Roberts, P. 2010. Biological and molecular diagnosis of seedborne viruses in cowpea germplasm of geographically diverse sub-Saharan origins. Plant Pathology 59:773-784. https:// doi.org/10.1111/j.1365-3059.2010. 02285.x.

Tamura, K. and Nei, M. 1993. Estimating the number of nucleotide substitutions in the control region of mitochondrial DNA in humans and chimpanzees. Molecular biology and Evolution 10(3):512-526. 10.1093/oxfordjournals.molbev.a040023.

Taiwo, M.A. 2003. Viruses infecting legumes in Nigeria/ : case history. In: Proceedings of a conference organized by IITA/ : 4-8 June 2001. International Institute of Tropical Agriculture. Ibadan, Nigeria. pp. 365-380.

Thompson, J.D., Gibson, T.J., Plewniak, F., Jeanmougin, F. and Higgins, D.G. 1997. 
The ClustalX windows interface: flexible strategies for multiple sequence alignment aided by quality analysis tools. Nucleic Acids Research 25:4876-4882.
Zheng, L., Rodoni, B.C., Gibbs, M.J. and Gibbs, A.J. 2010. A novel pair of universal primers for the detection of potyviruses. Plant Pathology 59(2):211-220. https:// doi.org/10.1111/j.1365-3059.2009. 02201.x. 